\title{
ŚWIĄTYNIE KULTU
}

CESARSKIEGO W STOLICACH

PROWINCJONALNYCH

W HISPANII (TARRACO, EMERITA

AUGUSTA, CORDUBA) - STATUS

\section{QUAESTIONIS}

\author{
Anna Zimnowodzka ${ }^{1}$ \\ https://doi.org/10.18778/8220-421-6.20
}

\begin{abstract}
The beginnings of the imperial cult in Hispania are connected with the reign of Augustus. According to Quintilian, an altar dedicated to him was erected in Tarraco (Hispania Citerior) when the emperor was still alive. After the death of the Emperor, on the 17th September AD 14 when he was deified and given the title of Divus Augustus, the inhabitants of Tarraco decided to dedicate a temple to him. Less than a year later, they asked Tiberius for permission to build it. The image of the temple on the coins of Tiberius, as well as the archaeological remains, excavated at the highest point of the city (on the site of the present cathedral), testify to the fact that the plan was realised. Shortly afterwards, the imperial cult spread to other provinces of Hispania (Ulterior Baetica, Ulterior Lusitania), and temples dedicated to the emperor decorated city forums in other cities, especially the provincial capitals. The example of Tarraco was followed by Emerita Augusta, where the so-called Temple of Diana was erected in the city
\end{abstract}

1 Mgr Filologii Iberyjskiej (UMCS Lublin) oraz doktor nauk humanistycznych w dziedzinie historia sztuki (KUL Lublin), azimnowodzka@o2.pl. 
forum and the Temple of Augustus in the provincial forum. As recent archaeological research shows, in Colonia Patricia Corduba, in the 1 st half of the 1st century, a temple in honour of the emperor was also built in the provincial forum, and in the 50 s of the 1st century - another one in the city forum.

Keywords: imperial cult, temple, Tarraco, Emerita Augusta, Colonia Patricia Corduba.

Słowa kluczowe: kult cesarski, świątynia, Tarraco, Emerita Augusta, Colonia Patricia Corduba.

Po śmierci Augusta w Noli 19 sierpnia 14 roku jego ciało zostało sprowadzone do Rzymu (Suet. Div. Aug. 100, Cass. Dio 56, 30). Tam, jak stwierdza Tacyt $(A n n .1,11)^{2}$, „według przyjętego zwyczaju”, odbył się pogrzeb cesarza. Jego „zwłoki zostały zaniesione na Pola Marsowe i spalone. Pewien były pretor przysięgał, że już po spaleniu zobaczył postać władcy ulatującego do nieba. Potem najznakomitsi spośród rycerstwa [...] zebrali szczątki i umieścili w Mauzoleum" (Suet. Div. Aug. 100)³. Na specjalnym posiedzeniu senatu 17 września 14 roku zmarłemu uchwalono świątynię i kult boski (divus Augustus) (Ibidem, 1, 10, por. Cass. Dio, 56, 46) ${ }^{4}$. Głównym ośrodkiem kultu nowego boga stała się wzniesiona przy Forum Augusta świątynia Marsa Mściciela (Ultor), której budowę sam August „ślubował jeszcze w czasie bitwy pod Filippi, podjętej jako akt zemsty za ojca” w 42 r. p.n.e. (Suet. Div. Aug. 29)5. Tam umieszczono jego eikon ( $\varepsilon_{i k \omega} \omega$ ) ze złota 6 , a konsulów zobowiązano do uroczystego świętowania jego urodzin (Cass. Dio, 56, 46).

Po deifikacji, do nadzorowania pośmiertnego kultu Augusta i całego rodu julijskiego, utworzono nowe kolegium kapłańskie

2 Wszystkie tłumaczenia pochodzą z wydania: Tacyt, 2004.

3 Wszystkie cytaty za: Gajus Swetoniusz Trankwillus, 1987.

4 Cyt. za: ibidem: 44. Na ten temat, zob. Jaczynowska, 1990: 129; Sajkowski, 2001: 28. Na temat pojęcia „kult cesarski”, zob. Olszewski, 2010: 361-377.

5 Na ten temat: zob. Sajkowski, 2001: 33.

6 Nie jest do końca jasny charakter eikon Augusta, badacze spierają się czy chodziło o złoty wizerunek cesarza czy o jego posąg. Na ten temat zob. Sajkowski, 2001: 51-52. 
Sodales Augustales (Tac. Ann. 1, 54). W jego skład weszło 21 członków: w tym przedstawiciele elity senatorskiej oraz członkowie rodziny cesarskiej (Tyberiusz, jego syn Druzus Młodszy, Germanik i późniejszy imperator Klaudiusz) (Tac. Ann. 1, 54)7. W szczególny sposób kultem boskiego Augusta miał się zajmować kapłan określany mianem flamen Augustalis, którym jako pierwszy został Germanik (Tac. Ann. 2, 54, 83) ${ }^{8}$. Honorowy ty tuł flaminica Augusti otrzymała Liwia (Cass. Dio, 56, 46).

Jak wynika z badań źródłowych i archeologicznych, kult cesarza stosunkowo szybko dotarł na Półwysep Iberyjski. Tam, podobnie jak w Urbs, zajmował się nim flamen Augustalis. Wyniki ostatnich badań pokazują, że świątynie ku czci Augusta oraz kolejnych cesarzy powstawały we wszystkich trzech, ustanowionych

7 Zadania kolegium sodales Augustales stawianego na równi z najważniejszymi kolegiami rzymskimi (pontifices, augures, quindecemviri sacris faciundis, septemviri epulones) obejmowały kult boskiego Augusta i gens Iulia. Jedną z najważniejszych uroczystości, w których brało udział były Augustalia, obchodzone od 3 do 12 października. Więcej na ten temat, zob. http://penelope.uchicago.edu/Thayer/E/Roman/Texts/secondary/SMIGRA*/ Augustales.html [11.05.2020]; Jaczynowska, 1990: 129, 139-140; Purcell, 1996: 802; Sajkowski, 2001: 34-40.

8 Choć nie ma co do tego pewności, niektórzy badacze powoływanie flamina wiążą z kontynuacją dotychczasowej tradycji - wyborem flamina Jowisza, a następnie Juliusza Cezara. Na flamen augustalis nakładano szczególne obowiązki oraz ograniczenia. Tytuł ten często nadawano potencjalnym następcom tronu. Więcej na ten temat, zob. Sajkowski, 2001: 40-47; http://penelope.uchicago.edu/Thayer/E/ Roman/Texts/secondary/SMIGRA*/Augustales.html [11.05.2020].

9 Tematem kultu cesarskiego na Półwyspie Iberyjskim zajmował się w latach pięćdziesiątych Robert Étienne, który napisał o tym szereg artykułów, między innymi: Étienne, R. (1988), Le culte impérial, vecteur de la hiérarchisation urbaine, $\mathrm{w}$ : Les villes de Lusitanie romaine. Hiérarchies et territoires, Talence, le 8-9 décembre, Paris: Edition du CNRS: 215-231, oraz obszerną monografię: idem (1958): Le culte impérial dans la Péninsule Ibérique d'Auguste a Dioclétien, "Bibliothèque des Écoles Françaises d'Athènes et de Rome" 191, Paris: E. De Boccard. 
przez samego Oktawiana Augusta w 27 roku p.n.e., prowincjach:

Tarraconensis, Lusitania, Baetica (Mar et al., 2015a: 222-224).

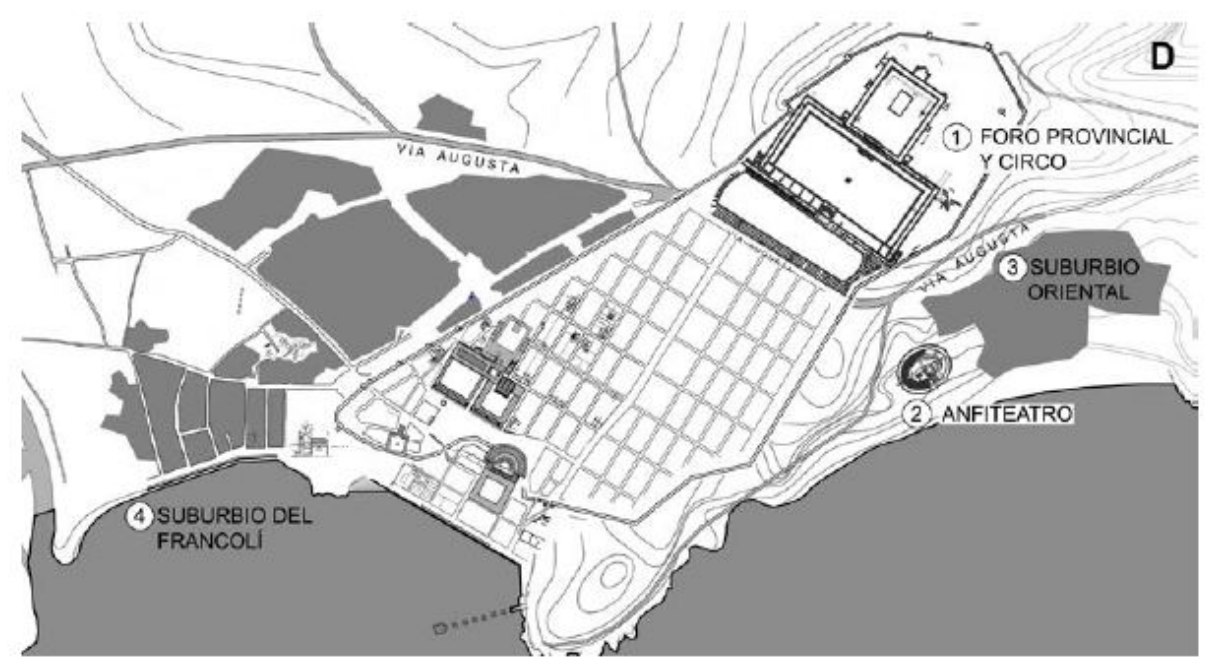

II. 1. Kompleks cesarski w górnej części miasta w I w. (numer 1): świątynia z portykiem, poniżej plac reprezentacyjny, na najniższym tarasie - cyrk (Mar et al., 2015b: 79).

Najwcześniej kult Augusta pojawił się w stolicy Tarraconensis - Tarraco. Jeszcze za życia Augusta mieszkańcy wznieśli na jego cześć, znany z wizerunku na monecie z okresu Tyberiusza, ołtarz. Mogło mieć to związek z pobytem samego cesarza w Tarraco, między 26 a 24 rokiem p.n.e. Wtedy to, w wyniku prowadzonych w północnej części Półwyspu wojen kantabryjskich „złożony chorobą z powodu nadmiernego wysiłku i osłabionego morale wycofał się [z pola walki] do Tarraco na rekonwalescencję" $\left(\right.$ Cass. Dio, 53, 25) ${ }^{10}$. Pobyt cesarza w Tarraco usiłowali umilić mu mieszkańcy miasta, wznosząc na jego cześć ołtarz (Quint. Inst. $6,3,77)$, którego lokalizacja w mieście nie została dotychczas rozstrzygnięta (Fishwick, 2014: 350-358; Macias et al., 2009: 426;

10 Wszystkie cytaty z dzieła Kasjusza Diona, o ile nie podano inaczej, pochodzą od autorki. Według Swetoniusza podczas walk cesarz doznał niemal śmiertelnego rażenia piorunem (Suet. Div. Aug. 29). 
Ruiz de Árbulo, 2009: 168-179). Rok po śmierci cesarza reprezentacja mieszkańców Tarragony zwróciła się do Tyberiusza z prośbą o wydanie zgody na wzniesienie świątyni na cześć zmarłego Augusta. Jak wspomina Tacyt: „na budowę świątyni Augusta [...] pozwolono proszącym o to Hiszpanom, czym dano dla wszystkich prowincji przykład" (Tac. Ann. 1, 78). O tym, że plan został wcielony w życie, świadczy wizerunek dedykowanej Augustowi świątyni na monetach z okresu Tyberiusza, a także wyniki badań archeologicznych (Macias et al., 2014: 1540n; Mar et al., 2015b: 84). Ta gigantyczna budowla stanowiła zwieńczenie potężnego, wzniesionego na trzech tarasach kompleksu budowli, na który składała się świątynia, plac reprezentacyjny oraz cyrk (il. 1).

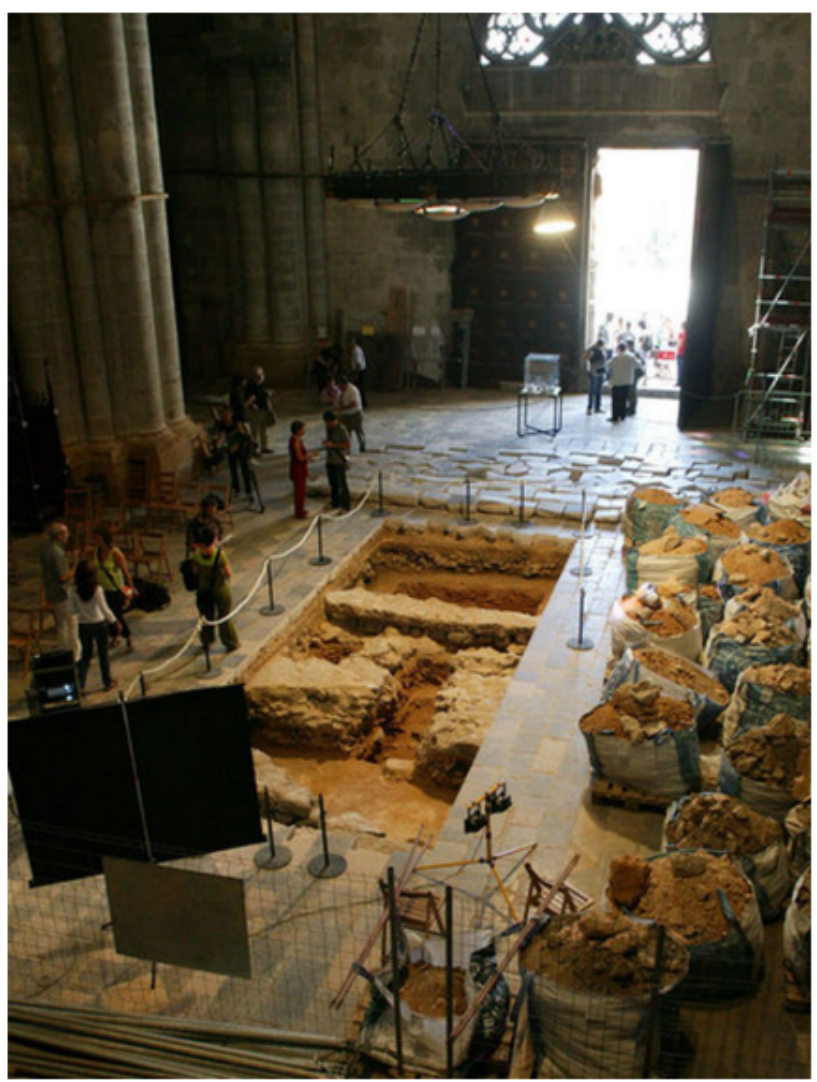

Il. 2. Pozostałości świątyni we wnętrzu katedry podczas prac archeologicznych źródło: https://elpais.com/cultura/2010/07/29/actualidad/1280354413_850215.html [11.05.2020]. 
Jego rekonstrukcję oraz etapy powstawania poszczególnych części zawdzięczamy wieloletnim badaniom rozpoczętym w latach 60-70 XX wieku i kontynuowanym w latach osiemdziesiątych. Ich ukoronowaniem były podjęte na początku XXI wieku (2010-2011) prace pod obecną katedrą, gdzie natrafiono na pozostałości świątyni (Macias Solé et al., 2010: 53, Macias et al., 2012: 6).

Udało się potwierdzić dotychczasowe podejrzenia badaczy, że przybytek ten stanął w najwyższym punkcie miasta, gdzie obecnie wznosi się katedra (Macias Solé et al., 2010: 52). Usytuowanie świątyni tak, by była widoczna z każdego punktu Tarraco, jej okazałe wymiary, a także dekoracja architektoniczna nawiązująca do wzorców rzymskich wydają się świadczyć o jej szczególnym znaczeniu. Jej wymiary mogły wynosić w przybliżeniu 27 x 47 metrów (Macias et al., 2012: 6) ${ }^{11}$. Do jej budowy po raz pierwszy w Tarraco użyto białego marmuru z Luni (Domingo, 2015: 191). Przy jej wznoszeniu pracowały warsztaty rzymskie, wzorujące się na świątyni Marsa Mściciela w Rzymie (Domingo, 2015: 191; Pensabene, Mar, 2010: 255, 258). Świątynia została przedstawiona na monecie z okresu Tyberiusza (ibidem: 76). Jej wygląd możemy odtworzyć również dzięki wynikom badań archeologicznych oraz zachowanym fragmentom dekoracji architektonicznej (Domingo, 2015: 191; Pensabene, Mar, 2010: 243-307). Był to okazały oktastylos, perypteros sine postico. Wejście do świątyni stanowiły schody (około $7 \mathrm{~m}^{3}$ ), co oznacza, że jej długość osiągała wraz z nimi około 53 metry (Macias et al., 2014: 1542). Fasadę zdobiły wysokie kolumny korynckie (13,5 metra). Wewnątrz znajdował się posąg boskiego Augusta o wysokości około 6 metrów. Budowla zwieńczona była fryzem (wysokim na 90,5 centymetra, grubym na 68 centymetrów i szerokim na 79 centymetrów) dekorowanym spiralnie zawiniętą

11 Ze względu na ograniczone możliwości badawcze pod posadzką katedry wymiary świątyni są podane w przybliżeniu, ich podane wartości różnią się w zależności od publikacji, na przykład: 27 x 35 metrów, zob. Macias Solé et al., 2010: 55; dla porównania: 27-28 x 39,75 metra, zob. Macias et al., 2014: 1542. 
wicią akantu (Pensabene, Mar, 2010: 259). Podobna dekoracja znajdowała się między innymi na Ara Pacis, fryzach świątyni Gajusza i Lucjusza (znanej jako „Maison Carrée”) w Nîmes oraz Romy i Augusta w Puli (Pensabene, Mar, 2010: 259)12.

W połowie I wieku wykopano i wypełniono na nowo rów, wytyczając wokół świątyni temenos (około 88,8 x 142,08 metra) (Macias Solé et al., 2010: 55). Za czasów Wespazjana, plac, na którym stała świątynia, powiększono do wymiarów około 153 x 133,10 metra (Mar et al., 2015a: 105) ${ }^{13}$ i z trzech stron otoczono portykiem (Ruiz de Árbulo et al., 2015a: 352-353). Od frontu zamknięto go murem i propylejami. Portyk z oknami (szerokimi na około 11 metrów i wysokimi na 10 metrów), wzniesiony został $\mathrm{z}$ lokalnego kamienia wapiennego $\mathrm{z}$ kamieniołomu Médol. Podobnie jak na forum Augusta w Rzymie, dekorowany był fryzem $\mathrm{z}$ ułożonych naprzemiennie płyt $\mathrm{z}$ kandelabrami oraz medalionami z wizerunkiem Jupitera Ammona lub Meduzy. Dekoracje wykonano z marmuru z Luni (Fishwick, 2004: 16; Macias et al., 2012: 8).

W okresie flawijskim w centralnej części portyku, tuż za świątynią, wybudowano budowlę określaną jako sala axial (szeroką na 27,5 metra, poprzedzoną fasadą o szerokości 29,7 metra). (Mar et al., 2015b: 110). Budowla ta miała być, zdaniem archeologów, przestrzenią dla kultu dynastii Fawiuszy. Przybytek zwieńczony był fryzem $z$ bukranionami, wśród których widoczne są także symbole kapłanów kultu cesarskiego (między innymi: apex - spiczasta czapeczka, aspergillum - kropidło do spryskiwania wodą oczyszczającą, culter - nóż ofiarny, simpulum - łyżkowaty czerpak do spełniania libacji oraz securis - siekiera do spełniania

12 Ze względu na masywny modelunek ornamentu wydaje się, że najbliższą analogią jest datowany na połowę I wieku fryz portalu Świątyni Romulusa na Forum Romanum lub ornament budowli nagrobkowej Falerii z okresu Nerona (Pensabene, Mar, 2004: 80).

13 Wymiary placu są przybliżone, ich wartości mogą nieznacznie różnić się w zależności od publikacji; na przykład 153 x 136 metrów (Ruiz de Árbulo, 2007: 29 i 35); 156,04 x 132,98 metra (Macias Solé et al., 2010: 57). 
ofiary krwawej), znane z fryzu świątyni Wespazjana w Rzymie (Pensabene, Mar, 2010: 264, 265).

W drugiej połowie I wieku (około 70 roku) do placu ze świątynią można było dostać się przez schody z propylejami z tarasu środkowego, na którym znajdował się, wykonany w marmurze karraryjskim plac reprezentacyjny (299,7 x 159,85 metra) (Macias et al., 2009: 429; Macias Solé et al., 2010: 56; McIntyre, 2016: 73n, TED'A, 1989). Otoczony z trzech stron portykiem, częściowo wysadzany zielenią, przeznaczony był do zebrań Rady Prowincjonalnej (Concilium provinciae Hispaniae Citerioris) (Macias Solé et al., 2010: 58; Macias et al., 2009: 429)14. Tu także miały miejsce ceremonie religijne, które kończyły się przy świątyni na najwyższym tarasie. Na placu stawiano posągi dedykowane prowincjonalnym flaminom, których liczne piedestały z inskrypcjami zachowały się do naszych czasów.

Za czasów cesarza Domicjana (81-96 r.), na najniższym z tarasów wybudowa no cyrk (Macias Solé et al., 2010: 54; Ruiz de Árbulo, Mar, 2001: 141-154; Mar et al., 2015b: 171-212).

Świątynia, która wieńczyła ten okazały kompleks, musiała mieć, zdaniem badaczy, szczególne znaczenie dla samego dworu cesarskiego również w późniejszych latach. Prace renowacyjne przeprowadzono za czasów Hadriana, który „[...] podążył do Hiszpanii i spędził zimę w Tarrakonie, gdzie własnym kosztem odbudował świątynię Augusta” (SHA, Hadr. 12, 3)15. Na początku III wieku, za czasów Septymiusza Sewera (193-211), świątynia po raz ostatni doczekała się odnowy. W tym czasie „wysłano Sewera do Hiszpanii; tam śniło mu się, że najpierw kazano mu odbudować świątynię Augusta w Terrakonie, chylącą się już ku upadkowi, a potem ze szczytu najwyższej góry patrzył na świat i Rzym, podczas gdy prowincje śpiewały przy dźwięku liry lub fletu" (SHA, Sept. 3, 4-5).

$14 \mathrm{Na}$ temat zadań i funkcjonowania Rady Prowincjonalnej w zachodniej części cesarstwa, zob. Kotula, T. (1968).

15 Wszystkie tłumaczenia tekstu SHA (Scriptores Historiae Augustae) na podstawie: Historycy cesarstwa rzymskiego, 1966. 


\section{Emerita Augusta}

Wydaje się, że w ślad za inicjatywą mieszkańców Tarraco podążyli również obywatele Emerity Augusty. Nie ma wątpliwości, że kilka lat po wzniesieniu świątyni Augusta w Tarragonie również w stolicy Luzytanii, na forum prowincji zaczęto budować dedykowaną mu kolejną świątynię (Fishwick, 1978: 1211-1213). Lokalni badacze uważają jednak, że kult cesarza był już obecny wcześniej w Emerita Augusta. Opierając się na wynikach badań archeologicznych z lat 80 . doszli do wniosku, że na forum kolonii wzniesiono w czasach Oktawiana Augusta świątynię dedykowaną Augustowi i Romie (Ayerbe Vélez et al., 2009: 809 (il. 3) ${ }^{16}$.

Plac pod forum ( $210 \times 104$ metry) został wyznaczony w samym centrum miasta (ibidem: 807; Ayerbe Vélez et al., 2011: 2). Jego poszczególne części zostały zaprojektowane tarasowo. Świątynia stanęła w jego północnej części, na platformie (59,06 x 49,20 metra), otoczonej z trzech stron budowlą w kształcie odwróconej litery „U”17. Przykrywała ona podziemną galerię - dwunawowy kryptoportyk, który zdaniem badaczy mógł służyć jako publiczny magazyn (Ayerbe Vélez et al., 2009: 811). Wejście do świątyni, poprzedzone schodami oraz rostra,

16 Do niedawna większość badaczy uważała, że kult Augusta i Romy był popularny za życia cesarza jedynie na wschodzie, i to w wybranych ośrodkach. Wydaje się jednak, że kult ten mógł być popularny również w zachodniej części cesarstwa. Zdania tego jest między innymi J.W. Stamper, który zauważa: „Even so, many thought of him as god, and the cult of his guardian spirit became established in many cities of the western Mediterranean region, with the building of temples dedicated to Rome and Augustus and oaths being taken in his name" (Stamper, 2005: 131). Zob. też Jaczynowska, 1990: 123-124, 126-127.

17 Budowla od XVII wieku nazywana jest Świątynią Diany. Nazwę tę zawdzięcza lokalnemu historykowi Bernabé Moreno de Vargasowi, który przyrównał ją wówczas do Artemizjonu w Efezie, zob. Moreno de Vargas, 1633: 31 (w tym wydaniu podany nr odnosi się do jednej dwustronicowej kartki). 
znajdowało się po stronie południowo-wschodniej, gdzie budowla otwierała się na plac publiczny. Z placu można się było do niej dostać poprzez dwa ciągi schodów, zlokalizowane od wschodu i zachodu. Po stronie zachodniej i wschodniej świątyni znajdowały się pozostałości niewielkich basenów. Świątynię - peripteros i heksastylos - (około 32,80 x 22 metry; 43,80 x 22 metry - ze schodami) zdobiły kolumny korynckie. Do budowy obiektu wykorzystano granit z okolicznych kamieniołomów okładany stiukiem (Ayerbe Vélez et al., 2009: 20, 809).

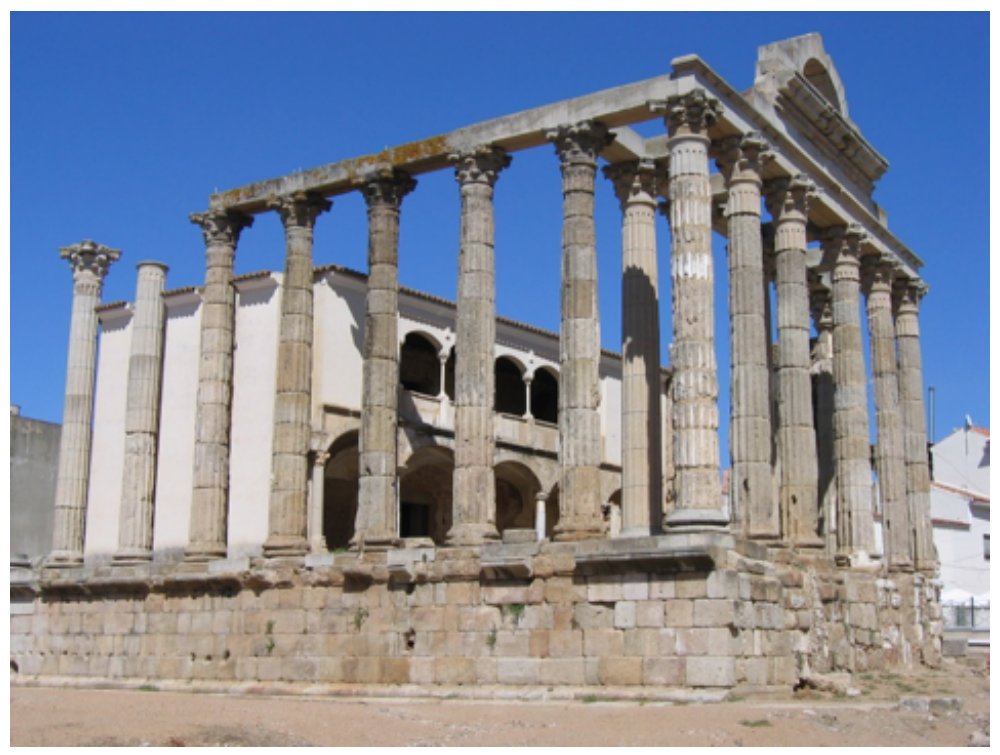

Il. 3. Świątynia dedykowana Augustowi i Romie (tzw. świątynia Diany) wzniesiona na Forum Kolonii (fot. Anna Zimnowodzka)

Świątynia przez kolejne lata nie ulegała większym zmianom, znaczące reformy dotknęły w połowie I wieku jej najbliższe otoczenie. Wówczas od południa dobudowano do forum bazylikę, od zachodu dwa place, natomiast po stronie wschodniej forum wyburzono dotychczasową zabudowę pod nowy, otoczony portykiem i wykładany płytami marmurowymi plac (64 x 74 metry), na którym stanęła kolejna świątynia. Ze względu na dekorację zachowanego częściowo portyku, nawiązującą do Forum Augusta 
w Rzymie, badacze powiązali świątynię z kultem Augusta. Ponieważ jednak materiał epigraficzny tego nie potwierdza, teoria ta wciąż wymaga potwierdzenia w planowanych dogłębnych pracach archeologicznych (Ayerbe Vélez et al., 2009: 764)18.

Mniej więcej w tym samym czasie, kiedy rozbudowano forum kolonii, dokonano przebudowy północnej części miasta (Ayerbe et al., 2010: 265; Mateos Cruz, 2006: 340; Mateos, Pizzo, 2009: 372-373). Wyburzono wówczas cztery kwartały z zabudową mieszkalną pod budowę forum prowincji, na którym, na wzór mieszkańców Tarraco, obywatele Emerity wznieśli świątynię dedykowaną cesarzowi Augustowi. Jej identyfikacji dokonano na podstawie inskrypcji „Concordiae Augusti” (Mateos, Pizzo, 2009: 371) oraz wyjątkowemu nagromadzeniu innych pozostałości archeologicznych. Wśród nich znalazły się między innymi fragmenty dekoracji, posągów mężczyzn w togach oraz inskrypcji datowanych na epokę Tyberiusza, Klaudiusza, Domicjana, Dioklecjana i Maksymiana, na których wymienia się lub wychwala cnoty kolejnych cesarzy, jeszcze w latach siedemdziesiątych wysunięto hipotezę o lokalizacji w pobliżu obecnego placu Plaza del Parador forum prowincjonalnego związanego z kultem cesarskim.

Badania te kontynuowano w 1983 roku, a następnie w latach 1999-2005 (Mateos, Pizzo, 2009: 371). Ustalono, że forum powstało najprawdopodobniej około 30 roku, za czasów cesarza Tyberiusza (Mateos, Pizzo, 2009: 372-373; Ayerbe et al., 2010: 265). Plac został podniesiony w stosunku do poprzedniego poziomu ulic miejskich. W całości został wyłożony marmurowymi płytami. Na jego obszar prowadziło sześć stopni i trójprzelotowy tak zwany „Łuk Trajana” (13,8 metra wysokości x 5,70 metra głębokości, arkada o rozpiętości 8,60 metra), wybudowany z granitowych

18 Wejście na platformę, na której wznosiła się świątynia, znajdowało się od strony forum poprzez schody, znajdujące się w portyku wschodnim Forum Kolonii. Wymiary odkrytej w 2006 roku świątyni wynoszą 20,24 x 40,40 metra. Wysoka na około 22,3 metra zdobiona była kolumnami korynckimi o wysokości 12,43 metra. Plac został wyłożony marmurowymi płytami, zob. Ayerbe Vélez et al., 2009: 764n. 
bloków i przykryty marmurowymi płytami. Plac otoczony został z trzech stron (od północy, wschodu i zachodu) portykiem (11 metrów wysokości x 9 metrów szerokości) (Ayerbe et al., 2010: 265; Mateos, Pizzo, 2009: 372). Od strony placu zdobiony został kolumnadą i w całości wyłożony marmurem (Ayerbe et al., 2010: 265). Do naroży portyku, od strony północnej, przylegały dwa trudne do zinterpretowania pomieszczenia, które wykraczały poza granice kompleksu (Ayerbe et al., 2010: 265).

W centrum placu wznosiła się potężna, wzorowana na rzymskiej Aedes Concordiae świątynia (Mateos Cruz, 2005: 139-141) (il. 4).

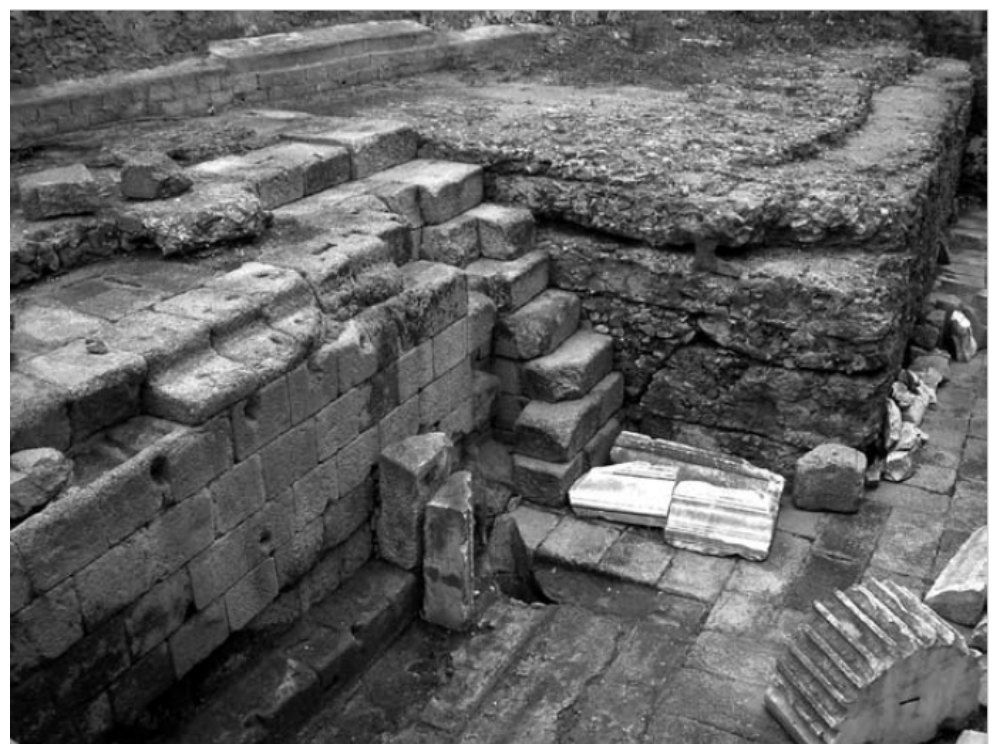

Il. 4. Pozostałości podium świątyni Augusta (Mateos, 2005: 381).

Była to zatem budowla określana przez badaczy jako „cella barlonga”, czyli taka, w której cella jest szersza od poprzedzającego ją pronaosu (38 x 32 metry, cella: 22 x 32 metry, pronaos: 18 x 22 metry) $)^{19}$. Wznosiła się na podium o wysokości 3,40-3,50 metra, była wysoka na około 26 metrów. Pronaos

19 Dla porównania: Świątynia Zgody w Rzymie: 45 x 24 metry, zob. Mateos Cruz, 2005: 141. 
zdobiony był kolumnami korynckimi. Prowadziło do niej dwanaście schodków (16 metrów szerokości) (Mateos Cruz, 2006: 256; idem, 2007: 382).

\section{2.}

\section{Colonia Patricia Corduba}

Do końca lat dziewięćdziesiątych wśród badaczy panowało zgodne przekonanie, że kult cesarski zawitał do stolicy Betyki (Colonia Patricia Corduba) najwcześniej za czasów dynastii Flawiuszów. Badacze bowiem dotychczas powoływali się na słowa Tacyta wspominającego delegację mieszkańców Corduby, którzy w 25 roku zwrócili się do cesarza z prośbą o wybudowanie świątyni dla panującego wówczas Tyberiusza i jego matki. Cesarz, zasłaniając się skromnością, odmówił proponowanego mu zaszczytu, zaznaczając, że o wiele bardziej uprawniony do odbierania kultu był jego poprzednik Oktawian August (Tac. Ann. 4, 37). W obliczu braku dodatkowych informacji u Tacyta oraz dowodów archeologicznych za pierwszą świątynię kultu cesarskiego uznano zatem, datowaną na połowę I wieku, budowlę przy obecnej ulicy Claudio Marcelo (we wschodniej części miasta) (Monterroso Checa, 2016: 84-91).

Rzeczywistość okazała się jednak bardziej złożona. Świadczą o tym wyniki badań archeologicznych prowadzonych w pierwszych latach XX wieku w okolicach obecnej ulicy Morería (w centralnej części miasta) (Carrasco, I, 2002: 199-208). Do tego czasu lokalizowano tam, powstałe w czasach republiki Forum Kolonii, zastąpione następnie forum cesarskim. W wyniku prowadzonych w 2002 roku badań ustalono, że do wspomnianego forum dobudowano od strony południowej, prawdopodobnie między 15 a 25 rokiem (Garriguet Mata, 2017: 126; Moreno, 2009: 107), dodatkowe forum aedictum, nazywane również forum novum (Garriguet Mata, 2017: 118; Moreno, 2009: 112).

W centrum otoczonego $\mathrm{z}$ trzech stron portykiem placu stanęła poprzedzona ołtarzem i orientowana w kierunku zachodnim 
świątynia (29,6 x 45 x 30 metrów wysokości) (Garriguet Mata, 2017: 118n; Portillo Gómez, 2016: 17-18). Wybudowana została w porządku korynckim. Jej fronton zdobiło osiem wysokich na 16 metrów kolumn (Garriguet Mata, 2017: 119; Portillo Gómez, 2016: 53-57, ibidem, 2017: 292). Większość dekoracji architektonicznej świątyni wykonana została $\mathrm{z}$ marmuru z Luni (około $1400 \mathrm{~m}^{3}$ ), co oznacza, że wzniesienie całego kompleksu świątynnego było niezwykle kosztowne. Najbliższą analogię dla dekoracji budowli stanowi świątynia Marsa Mściciela w Rzymie (Garriguet Mata, 2017: 118-119; Peña et al., 2016: 18, 61). Podobieństwo do przybytku Augusta w Rzymie jest tak duże, że badacze skłonni są podejrzewać, że przy jej wznoszeniu pracowały warsztaty sprowadzone ze stolicy (Garriguet Mata, 2017: 120; Potrillo, 2016: 79-82). O ile datowanie budowli na pierwszą połowę I wieku nie budzi zastrzeżeń badaczy, o tyle wątpliwości wzbudza brak jednoznacznego potwierdzenia w tekstach źródłowych oraz bardzo skąpy materiał epigraficzny ${ }^{20}$. Mimo bardzo przekonującego materiału architektonicznego i dekoracyjnego wciąż trudno rozstrzygnąć, czy była to pierwsza świątynia kultu cesarskiego w $\mathrm{Co}$ lonia Patricia Corduba.

Badacze nie mają jednak wątpliwości, że takim przybytkiem była przywołana wcześniej świątynia przy ulicy Claudio

20 Wśród materiału epigraficznego na szczególną uwagę zasługuje wykonany na dwóch marmurowych płytach z Luni napis dedykacyjny ze złotych liter (litterae aureae). Wykorzystane do wzniesienia średniowiecznego muru płyty, pochodzą, zdaniem badaczy, z fryzu dedykacyjnego świątyni przy ul. Morería. Wielkość zachowanych liter, tworzących dwa rzędy tekstu $(86 \mathrm{~cm})$, jest identyczna jak w analogicznym napisie dedykacyjnym świątyni Marsa Mściciela w Rzymie. Tekst jest rekonstruowany w następujący sposób: „[Divo Caesa]ri Au[gusto patri patriae]/[permissu Ti. Ca] esar[is Divi Augusti f(ili)/Augusti]”, zob. Stilow, Ventura, 2013: 310-311. Wśród materiału epigraficznego z okolic świątyni są cztery piedestały $z$ inskrypcjami dedykowanymi kapłanom prowincjonalnym. Najstarszy znaleziony piedestał dedykowany kapłanowi prowincjonalnemu $\mathrm{z}$ tej okolicy datowany jest na II wiek. Szerzej na ten temat, zob. Potrillo, 2016: 209-210; Garriguet Mata, 2017: 114-116. 
Marcelo wzniesiona między 50 a 55 rokiem (Santos Gener, 1955: 121) (il. 5).

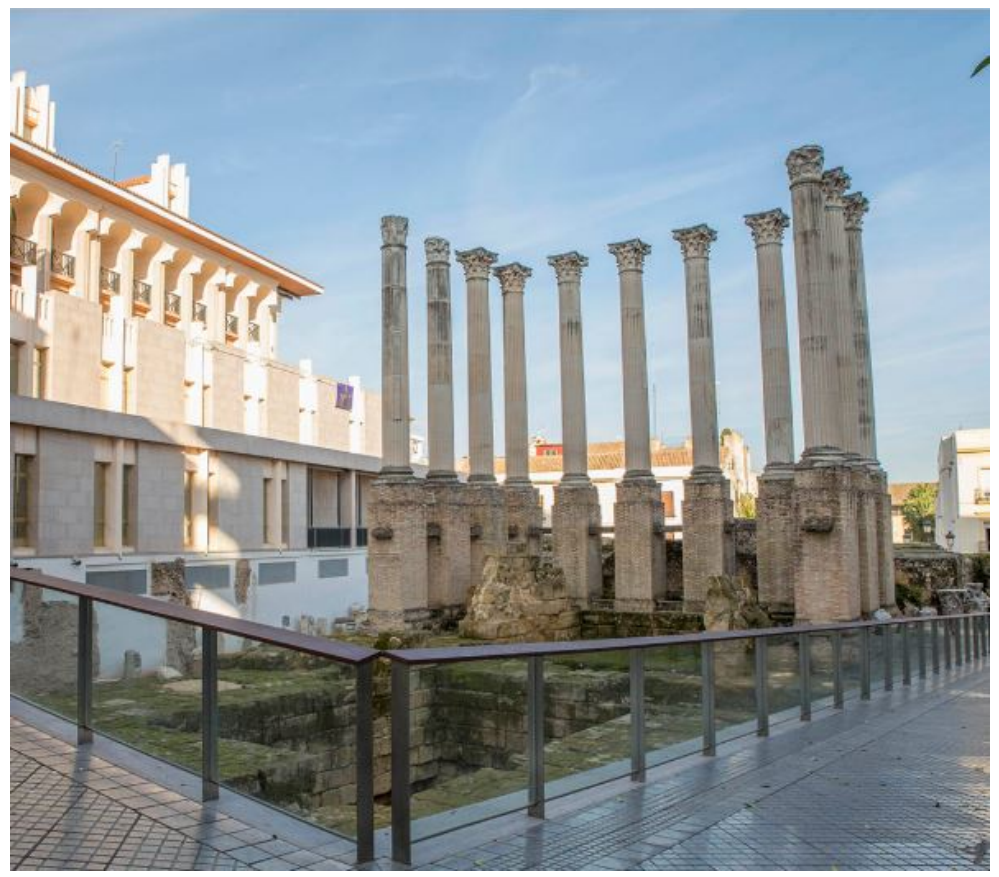

Il. 5. Świątynia przy ul. Claudio Marcelo źródło: https://www.artencordoba.com/cordoba-romana/FOTOS/TEMPLO/TEMPLO_ ROMANO_CORDOBA_06.jpg [11.05.2020].

Przypuszcza się, że dedykowana była cesarzowi Klaudiuszowi, o czym miałoby świadczyć znalezione w tej okolicy, datowane na I wiek, popiersie boskiego Klaudiusza. Na jej pozostałości natrafiono podczas prac budowlanych przy ratuszu miejskim w 1951 roku (Gutiérrez Deza, 2015: 51-52; Murillo et al., 2003: 54; Santos Gener, 1955: 121). Prace kontynuowano w 1958 roku, a następnie w 1985 roku. Największym zaskoczeniem okazały się jednak wyniki prac prowadzonych w latach 1994-1995 przy portyku otaczającym świątynię oraz w najbliższym otoczeniu świątyni. Na wschód od przybytku natrafiono bowiem na pozostałości placu oraz cyrku, które, jak się okazało, były z nim 
skomunikowane tarasowo (Gutiérrez Deza, 2015: 56-60; Murillo et al., 2003: 54, przyp. 2).

Na podstawie zebranych materiałów ustalono zatem, że świątynia górowała nad złożonym z trzech tarasów kompleksem, na który składał się plac, gdzie się wznosiła, pośredni taras pełniący rolę placu reprezentacyjnego oraz cyrk. Ze względu na podobieństwo do założenia w Tarraco, część badaczy skłania się do podejrzeń, że chodzi tu o kompleks kultu prowincjonalnego dla Betyki, (Fishwick, 1991: 219-239, 261-262; Garriguet Mata, 1997: 58). Świątynia, która stanęła na najwyżej położonym tarasie (70 x 70 metrów), od północy, zachodu i południa otoczona była portykiem. Był to heksastylos o pokaźnych wymiarach: 16 x 32 x 17/18 metrów wysokości. (Gutiérrez Deza, 2015: 161; Murillo et al., 2003: 58; Jiménez Salvador, 1992: 125). Fasadę świątyni zdobiły kolumny korynckie z marmuru z Luni (Gutiérrez Deza, 2015: 43). Najbliższą analogią dla niej jest Maison Carreé w Nîmes (idem: 52, 161, 164; Jiménez Salvador, 1992: 125).

\section{Podsumowanie}

Jak wydają się wskazywać wyniki badań archeologicznych, epigraficznych i źródłowych, kult cesarza Augusta na Półwyspie Iberyjskim, okazywany był jeszcze za życia princepsa poprzez czczenie jego geniusza przy ołtarzu w Tarraco i być może w tak zwanej Świątyni Diany w Emerita Augusta (w której czczona miała być również bogini Roma). W sposób wyjątkowy jednak kult cesarski rozwinął się tuż po śmierci władcy, we wszystkich trzech stolicach prowincjonalnych Hispanii. Rozpoczęto wówczas wznoszenie monumentalnych świątyń, które, jak się wydaje, zdobiły przede wszystkim nowo powstające fora prowincji.

Wzorem dla budowniczych były bez wątpienia najbardziej okazałe świątynie rzymskie, ze szczególnym uwzględnieniem świątyni Marsa Mściciela oraz Świątyni Zgody. Architekci usiłowali dosyć dokładnie naśladować wielkie świątynie rzymskie, często jednak „musieli tworzyć plany odpowiadające lokalnej rzeczywistości” (Zanker, 1999: 307). Ponieważ wznoszono je 
według podobnych reguł obowiązujących we wszystkich częściach cesarstwa, można w przybliżeniu określić czas ich powstania. Były, w przeciwieństwie do dawnych świątyń (jak na przykład tak zwana Świątynia Diany w Emerita Augusta), z reguły budowane z marmuru lub przynajmniej nim okładane.

Jak zauważa Paul Zanker (1999: 307): „Mimo różnic w detalach zawsze wyłania się ten sam obraz, zgodny ze złotymi świątyniami (aurea templa) princepsa w Rzymie. Zawsze mamy do czynienia ze świątynią posiadającą podium, reprezentacyjne schody wejściowe, wysokie kolumny korynckie, bogato zdobione belkowanie, kosztowne gzymsy. Zawsze przywiązywano szczególną wagę do wyglądu fasady. [...]. Nigdzie nie szczędzono pieniędzy na skomplikowane kielichy kwiatów, woluty, jak również na niekończące się fryzy ozdobione pędami latorośli".

Trzeba przyznać, że coraz bogatszy materiał archeologiczny gromadzony i weryfikowany podczas wieloletnich prac wykopaliskowych w znacznym stopniu przyczynił się do odtworzenia wyglądu wszystkich świątyń kultu cesarskiego w stolicach prowincjonalnych Hispanii. Jednak ich stan zachowania i trudności z dostępem do zachowanych pozostałości ukrytych pod zabudową miejską znacząco ograniczają możliwość w pełni prawidłowego zrekonstruowania przybytków. $Z$ tego powodu, badania nad świątyniami kultu cesarskiego w stolicach prowincjonalnych Hispanii powinniśmy uznać za proces wciąż niezakończony.

\section{Bibliografia}

Ayerbe Vélez, R., Barrientos Vera, T., Palma García, F. (red.) (2009): Génesis y evolución del Foro de Augusta Emerita. „Anejos de Archivo Español de Arqueología" 53: 807-831.

Ayerbe Vélez, R., Barrientos Vera, T., Palma García, F. (2011): Los complejos monumentales forenses de Augusta Emerita. Arquitectura y urbanismo, w: J.M. Alvárez Martínez, I. Mateos Carrasco (red.) (2002): Intervención arqueológica de urgencia en un solar sito en calle Góngora número 13 esquina a calle Teniente Braulio Laportilla (Córdoba). „Anuario Arqueológico de Andalucía" 97, 3: 199-208. 
Ayerbe, R., Barrientos, T., Mateos, P., Palma, F., Pizzo, A. (2010): El urbanismo del conjunto provincial de culto imperial y del foro de Augusta Emerita, w: T. Nogales Basarrate (red.), Ciudad y foro en la Lusitania Romana. Mérida: Museo Nacional de Arte Romano de Mérida: 261-271.

Cassius Dio Cocceianus (1925): Historiae Romanae Dio's Roman History. E. Cary (tłum.), London: W. Heinemann, New York: G.P. Putnam Sons.

Cruz, P. (red.), Actas Congreso Internacional 1910-2010: El Yacimiento Emeritense. Mérida: Ayuntamiento de Mérida: 209-228.

Domingo, J.Á. (2015): El templo de Augusto en Tarraco, A. Caecina Severus y la estandarización de la arquitectura gigantesca, w: J. López Vilar (red.), August i les províncies occidentals 2000 aniversari de la mort d'August. Tarragona: Impremta Torrell: 191-196.

Fishwick, D. (1978): The Development of Provincial Ruler Worship in the Western Roman Empire. „Anuario de historia del derecho español" II 16.2: 1201-1253.

Fishwick, D. (2004): The Imperial Cult in the Latin West, Volume III, Provincial Cult. Part 3. Leiden: Brill.

Fishwick, D. (2014): The status and location of the altar of Augustus at Tarraco. „Phoenix” 68, 3-4: 350-358.

Gajus Swetoniusz Trankwillus (1987): Żywoty Cezarów, J. Niemirska-Pliszczyńska (tłum.). Wrocław: Ossolineum.

Garriguet Mata, J.A. (2007): La decoración escultórica del templo romano de las calles Claudio Marcelo - Capitulares y su entorno (Córdoba). Revisión y novedades, w: T. Nogales, J. González (red.), Culto Imperial: política y poder. (Actas del Congreso Internacional, Mérida Museo Nacional de Arte Romano, 18-20 de mayo, 2006). Roma: L’Erma di Bretschneider: 299-321.

Garriguet Mata, J.A. (2017): Tácito, el templo romano de la c/Morería (Córdoba) y el origendel culto provincial en Baetica. "Zephyrus” 80: 113-130.

Gutiérrez Deza, M.I. (2015): Análisis de un centro de culto imperial de la Córdoba romana: el conjunto arquitectónico de la c/Claudio Marcelo. Córdoba: Servicio de Publicaciones de la Universidad de Córdoba. 
Historycy cesarstwa rzymskiego. Żywoty cesarzy od Hadriana do Numeriana, (1966), H. Szelest (tłum. i oprac.). Warszawa: Czytelnik.

„Institutio Oratoria” by Quintilian, (1977): H.E. Buttler (tłum.). Cambridge-Massachusetts-London: Loeb Classical Library, t. 2. Jaczynowska, M. (1990): Religie świata rzymskiego. Warszawa: PWN.

Jiménez Salvador, J.L. (1992): El templo romano de la calle Claudio Marcelo en Córdoba, w: Templos Romanos de Hispania. Cuadernos de Arquitectura Romana 1. Murcia: Colegio Oficial de Arquitectos, Universidad de Murcia: 119-132.

Kotula T. (1968): Zgromadzenie prowincjonalne $w$ rzymskich prowincjach okresu wczesnego cesarstwa: (w zwiazku z ksiażka J. Deiningera, Die Provinziallandtage der römischen Kaiserzeit von Augustus bis zum Ende des dritten ahrhunderts n. Chr., München 1965), „Przegląd Historyczny”, 59, 3: 501-506.

Macias, J.M., Menchón, J., Muñoz, A., Teixell, I. (2009): La construcción del recinto imperial de Tarraco (provincia Hispania Citerior). „Butlletí Arqueològic” 5, 32: 423-479.

Macias, J.M., Muñoz, A., Peña, A., Teixell, I. (2014): El templo de Augusto en Tarraco: últimas excavaciones y hallazgos, w: J.M. Álvarez et al. (red.): XVIII Congreso Internacional de Arqueología Clásica, t. 2, Mérida: Museo Nacional del Arte Romano: 1539-1543.

Macias, J.M., Muñoz Melgar, A., Peña Jurado, A., Ramón Mas, M., Teixell Navarro, I. (2012): Praesidium, templum et ecclesia. Les intervencions arqueologiques a la catedral de Tarragona 2010-2011 - memòria d'una exposició temporal. Tarragona: Associació Cultural Sant Fructuós, Capítol de la Catedral de Tarragona, Conselleria de Patrimoni Històric de l'Ajuntament de Tarragona, ICAC, Museu Bíblic Tarraconense.

Macias Solé, J.M., Menchón Bes, J.J., Muñoz Melgar, A., Teixell Navarro, I. (2010): La acrópolis de Tarraco y la implantación urbana del culto imperial en la capital de la Hispania Citerior. „Bollettino di Archeologia on line”, wydanie specjalne A/A8/4: $50-60$. 
Mar, R., Ruiz de Árbulo, J., Vivó, D., Beltrán-Caballero, J.A. (2015a): Tarraco. Arquitectura y urbanismo de una capital provincial romana. Tarragona: t. 1.

Mar, R., Ruiz de Árbulo, J., Vivó, D., Beltrán-Caballero, J.A. (2015b): Tarraco. Arquitectura y urbanismo de una capital provincial romana. Tarragona: Universitat Rovira i Virgili, t. 2.

Moreno, C. (2009): Transformaciones en los foros de Colonia Patricia, w: J.M. Noguera (red.), Fora Hispaniae. Paisaje urbano, arquitectura, programa decorativo y culto imperial en las ciudades hispanorromanas. Murcia: 105-121.

Mateos Cruz, P. (2005): El templo de culto imperial de Augusta Emerita, w: Simulacra Romae. Roma y los capitales provinciales del occidente europeo: Estudios Arqueológicos. Alicante: Biblioteca Virtual Miguel de Cervantes: 129-147.

Mateos Cruz, P. (2007): El conjunto provincial de Culto Imperial de Augusta Emerita, w: T. Nogales, J. González (red.), Culto Imperial: política y poder. Roma: "L'Erma" di Bretschneider: 369-394.

Mateos Cruz, P. (2006): El foro provincial de Augusta Emerita. Un conjunto monumental de culto imperial. „Anejos de Archivo Español de Arqueología" 42.

Mateos, P., Pizzo, A. (2009): El Conjunto Provincial de culto Imperial de Augusta Emerita. „Anejos de Archivo Español de Arqueología" 45: 371-382.

Monterroso Checa, A. (2016): El templo de la calle Claudio Marcelo. La identidad romana de su inserción topográfica, w: M.D. Baena, C. Márquez, D. Vaquerizo (red.), Córdoba. Reflejo de Roma. Córdoba: Diputación de Córdoba: 84-91.

Murillo, J.F., Moreno, M., Jiménez, J.L., Ruiz, D. (2003): El templo de la c/ Claudio Marcelo (Córdoba). Aproximación al foro provincial de la Bética. „Romvla” 2: 53-88.

Nogales Basarrate, T., Álvarez Martínez, J.M. (2006): Foros de Augusta Emerita. Espacios y símbolos de poder en Hispania, w: M. Navarro Caballero, J.M. Roddaz (red.), La transmission de l'idéologie impériale dans l'occident romain. Bordeaux: Ausonius Éditions: 129-177. 
Olszewski, L. (2010): „Religia” i „kult cesarski” w starożytnym Rzymie - ż̇ycia pojęć, w: Sz. Olszaniec, P. Wojciechowski (red.): Społeczeństwo i religia w świecie antycznym. Toruń: Wydawnictwo Naukowe Uniwersytetu Mikołaja Kopernika: 361-377.

Pensabene, P., Mar, R. (2010): Il tempio di Augusto a Tarraco: gigantismo e marmo lunense nei luoghi di culto imperiale in $\mathrm{Hi}$ spania e Gallia. „Archeologia Classica” 61, 11: 243-307.

Peña, A., Ventura, A., Potrillo, A. (2016): El templo consagrado a divo Augusto y su temenos (Forum Novum), w: Córdoba, reflejo de Roma. Córdoba: 59-67.

Portillo Gómez, A. (2016): El templo de la calle Morería en el Forum Novum de Colonia Patricia Corduba. Análisis arquitectónico y funcional. Córdoba: Universidad de Córdoba.

Portillo Gómez, A. (2017): La decoración arquitectónica del templo de la calle Morería. „Thiasos Monografie” 9: 281-294.

Ruiz de Árbulo, J. (2009): El altar y el templo de Augusto en la colonia Tarraco. Estado de la cuestión, w: J.M. Noguera Celdrán (red.), Fora Hispaniae. Paisaje urbano, arquitectura, programas decorativos y culto imperial en los foros de las ciudades hispanorromanas. Murcia: Universidad de Murcia: 155-189.

Sajkowski, R. (2001): Divus Augustus Pater. Kult boskiego Augusta za rządów dynastii julijsko-klaudyjskiej. Olsztyn: Wydawnictwo Uniwersytetu Warmińsko-Mazurskiego.

Santos Gener, S. (1955): Memoria de las Excavaciones del Plan Nacional, realizadas en Córdoba (1948-1950). Madrid: Ministerio de Educación Nacional.

Tacyt (2004): Dzieła, S. Hammer (tłum.). Warszawa: Czytelnik. TED'A (1989): El Foro Provincial de Tarraco: un complejo arquitectónico de ceremonias de época flavia, „Archivo Español de Arqueología" 62. 